\title{
Mechanical and Gas Barrier Properties of Nylon 6/Clay Nanocomposite Blown Films
}

\section{Anongnat Somwangthanaroj ${ }^{1, *}$, Mongkol Tantiviwattanawongsa ${ }^{1}$, and Wiwut Tanthapanichakoon ${ }^{1,2}$}

1 Department of Chemical Engineering, Faculty of Engineering, Chulalongkorn University, Bangkok 10330, Thailand

2 Department of Chemical Engineering, Graduate School of Science and Engineering, Tokyo Institute of Technology, Tokyo 152-8552, Japan

Email: anongnat.s@chula.ac.th*

\begin{abstract}
Nylon 6/clay nanocomposite films were prepared by melt mixing nylon 6 with organoclay using a twin screw extruder attached to a blown film die. The type of surfactant used in the pretreatment of organoclay was expected to affect the degree of clay dispersion, which would in turn affect the degree of crystallinity, crystalline phase and bulk properties of the polymer composite. Two different surfactants used to treat the surface of montmorillonite clay were trimethyl tallow quaternary ammonium chloride $\left(\mathrm{M}_{3} \mathrm{~T}\right.$, a singlechain surfactant) and dimethyl bis (hydrogenated-tallow) ammonium chloride $\left(\mathrm{M}_{2}(\mathrm{HT})_{2}\right.$, a double-chain surfactant). The addition of the resulting organoclay into nylon 6 was found to enhance the formation of $\gamma$-phase and increase the degree of crystallinity and crystallization temperature of the nylon 6. In fact nanocomposite films containing the single-chain surfactant showed a higher degree of clay dispersion in nylon 6 matrix, up to $148 \%$ higher stiffness and up to $100 \%$ lower oxygen permeability than those films containing the corresponding double-chain surfactant at the same inorganic loadings investigated. As expected, the nanocomposite films exhibited 58\% higher stiffness in the machine direction than the transverse direction.
\end{abstract}

Keywords: Nanocomposites, nylon 6, organoclay, mechanical properties, gas barrier properties, microstructure.

ENGINEERING JOURNAL Volume 16 Issue 2

Received 14 November 2011

Accepted 7 March 2012

Published 1 April 2012

Online at http://www.engj.org

DOI:10.4186/ej.2012.16.2.93 


\section{Introduction}

The addition of inorganic fillers into polymers is well known as an economical way to improve the properties of the polymers. Recently, compounded polymers with layered silicates have been prepared with significantly enhanced solid-state mechanical [1-10], gas barrier [3-5, 10-17], thermal [3, 4, 6, 7, 9, 11, 12, 18] and other physicochemical properties $[2,9,11]$. These enhancements could be achieved at low clay loadings, typically in the range of $1-10 \mathrm{wt} \%$. For example, the tensile modulus and oxygen gas barrier properties of LDPE/clay nanocomposite films at $7 \mathrm{wt} \%$ concentration was doubled and reduced by three fourths, respectively, compared to those of neat LDPE [10]. Undoubtedly, the enhanced polymer/clay nanocomposites will find use as new materials in automotive, electronic/ high-tech packaging and aerospace applications.

The production of polymer/clay nanocomposite is generally accomplished by two methods: in-situ polymerization $[12,17,19-21]$ and melt mixing methods $[1,2,4-7,10,11,13]$. Obviously, the melt mixing method is easier and more cost effective to prepare nanocomposites. To achieve good dispersion of the layered silicates in the polymer matrix, the inorganic clay surface must be treated by ion exchange with an organic cation such as alkyl ammonium ion to obtain organophilic clay or organoclay.

Nylon 6 films are widely used in packaging due to their superb properties such as high strength, high stiffness, good toughness, low gas and vapor permeability, and high transparency. The Toyota group first prepared nylon 6/clay nanocomposites by in situ polymerization method [20]. Added with only a small amount of clay, the nanocomposites exhibited superior mechanical and thermal properties. The nylon 6/clay nanocomposite films have high potential for application in the packaging field, especially food packaging, because they are expected to exhibit improved mechanical and gas barrier properties while maintaining high transparency. The enhancement of the gas barrier property results from the tortuous pathways of the gas around the silicate platelets through the nanocomposite films. In fact, the high aspect ratio of the organoclay platelets also contributes to enhance mechanical performance. As expected, the gas barrier property increases as the organoclay loading increases [4, 5, 11-13]. In addition, the crystalline structure of the matrix polymer also affects both the gas barrier and mechanical properties[22]. An increase in the degree of crystallinity affects the gas permeability due to the reduction in the free volume of the amorphous phase of the polymer matrix, including nylon 6 [11].

A semi crystalline polymer, nylon 6 can assume two crystalline structures, namely, $\alpha$ - and $\gamma$-crystalline forms, depending on several factors. Generally, quenching or rapid cooling enhances the $\gamma$-crystalline form of nylon 6 while the $\alpha$-crystalline form is produced predominantly under slow cooling condition. In fact the $\gamma$-crystalline structure is produced predominantly when the mobility of the polymer chains are limited [18, 23, 24]. Interestingly, the addition of layered silicates into the nylon 6 matrix was found to affect the orientation of crystallites of nylon 6 [25] as well as enhance the formation of the $\gamma$-crystalline phase of nylon 6 while its $\alpha$ crystalline phase still remained in the nylon $6 /$ clay nanocomposites.

The present study is focused on the solid-state properties of nylon $6 /$ clay nanocomposite films made by melt-mixing process intended for air-tight packaging applications. More specifically, the role played by the chemical structure of the surfactant on the degree of clay dispersion in the nylon 6 matrix, which in turn affects the crystal structure and degree of crystallinity of the nylon 6 in the nanocomposite films will be examined. The effects of the number of long chain of surfactants and organoclay loading on the resulting mechanical and gas barrier properties of the nanocomposite films will also be investigated.

\section{Experiments}

\subsection{Materials}

Nylon 6 was obtained from Ube Nylon, Thailand. It had average molecular weight (MW) of 22,000 $\mathrm{g} \cdot \mathrm{mol}^{-1}$ and specific gravity of 1.14. Na-montmorillonite with cation exchange capacity (CEC) of $0.9 \mathrm{meq}^{-1}$ (following ASTM C 837) was supplied by Kunimine Industrial Co., Ltd., Japan. Supplied by Akzo Nobel Co., Ltd., Thailand, the surfactants used for ion-exchange reaction were trimethyl tallow quaternary ammonium chloride $\left(\mathrm{M}_{3} \mathrm{TN}^{+} \mathrm{Cl}\right)\left(\mathrm{MW}=347.5 \mathrm{~g} \cdot \mathrm{mol}^{-1}\right.$ and 50 assay $\left.\%\right)$ and dimethyl bis (hydrogenatedtallow) ammonium chloride $\left(\mathrm{M}_{2}(\mathrm{HT})_{2} \mathrm{~N}^{+} \mathrm{Cl}\right)\left(\mathrm{MW}=585.5 \mathrm{~g} \cdot \mathrm{mol}^{-1}\right.$ and 75 assay \%). Their structures are shown in Fig. 1. 
(a)

(b)
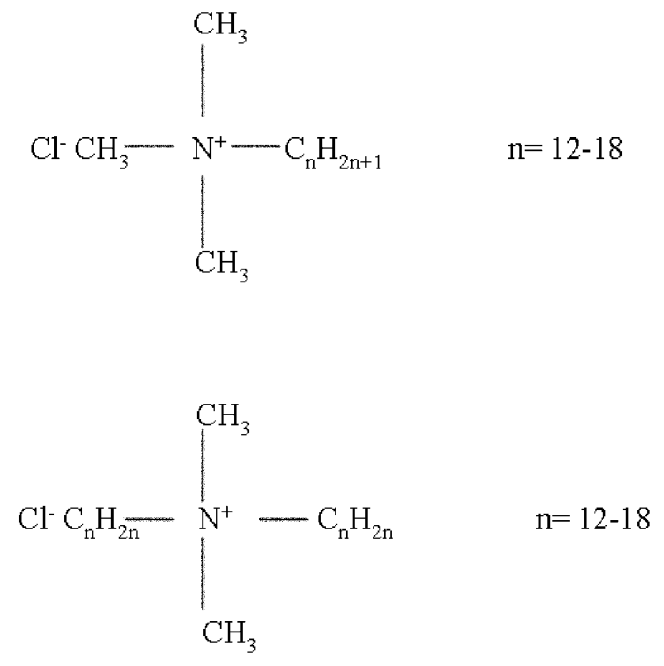

Fig. 1. Molecular structure of (a) trimethyl tallow quaternary ammonium chloride $\left(\mathrm{M}_{3} \mathrm{~T}\right)$ and (b) dimethyl bis (hydrogenated-tallow) ammonium chloride $\left(\mathrm{M}_{2}(\mathrm{HT})_{2}\right)$.

\subsection{Methods}

\subsubsection{Surface modification of montmorillonite}

The surfaces of the Na-montmorillonite were modified with the above-mentioned ammonium salts via ion exchange to obtain the corresponding organoclays. First, Na-montmorillonite powder in water was heated up to $70{ }^{\circ} \mathrm{C}$ while being stirred intensively for 3 hours. The Na-montmorillonite suspension was then mixed with the surfactant solution of interest. The solid part was filtered out, washed with distilled water for at least 3 times and then dried in an oven at $80{ }^{\circ} \mathrm{C}$ for 3 to 4 days. The dried solid was mortared and sieved to control the maximum particle size. The clay treated with trimethyl tallow quaternary ammonium chloride $\left(\mathrm{M}_{3} \mathrm{TNN}^{+} \mathrm{Cl}\right)$ and dimethyl bis (hydrogenated-tallow) ammonium chloride $\left(\mathrm{M}_{2}(\mathrm{HT})_{2} \mathrm{~N}^{+} \mathrm{Cl}\right)$ was designated as $\mathrm{M}_{3} \mathrm{~T}$ and $\mathrm{M}_{2}(\mathrm{HT})_{2}$ organoclay, respectively.

\subsubsection{Preparation of nylon 6/clay nanocomposite films}

The organoclay and nylon 6 were separately dried in a vacuum oven at $80{ }^{\circ} \mathrm{C}$ for at least 24 hours to completely remove all absorbed moisture. To obtain nylon $6 /$ clay nanocomposite films with different organoclay loadings $(1,3,5$ and $7 \mathrm{wt} \%)$, the two raw materials were melt mixed using a co-rotating twinscrew extruder $(\mathrm{L} / \mathrm{D}=25$ and $\mathrm{D}=16 \mathrm{~mm}$ ) attached to a $24 \mathrm{~mm}$ diameter blown film die (Thermo Haake, Rheomex, Germany) operated at a barrel temperature of $250{ }^{\circ} \mathrm{C}$ and a screw speed of $200 \mathrm{rpm}$. The thickness of all films is in the range of $50 \pm 5 \mu \mathrm{m}$.

\subsubsection{Characterization of the nanocomposite films}

XRD patterns of the layered silicates in the pristine clay, organoclay powder and nylon $6 /$ clay nanocomposite films as well as the crystalline phase of the nylon 6 matrix were obtained with a diffractometer (Bruker AXS: D8 Discover model) using CuK $\alpha$ radiation of wavelength $1.542 \AA$ and scanning in the range of $2 \theta=1-10^{\circ}$ and $2 \theta=18-28^{\circ}$ at a rate of 0.0125 degree $\cdot \min ^{-1}$. The voltage and current used in these analyses were $40 \mathrm{kV}$ and $40 \mathrm{~mA}$, respectively. The interlayer spacing of the clay platelets was estimated via Bragg's equation. The dispersion state of the layered silicates in the nylon 6/clay nanocomposite films was observed by means of transmission electron microscopy (TEM, JEM-2010 JEOL, Japan) at an accelerating voltage of $200 \mathrm{kV}$. To do this, the films were first embedded in epoxy resin and ultra-thin sections of $80 \mathrm{~nm}$ thickness of the nanocomposite films were then obtained under cryogenic condition $\left(-10^{\circ} \mathrm{C}\right)$, using cryo-ultramicrotome. 
The crystalline-melting temperatures $(\mathrm{Tm})$ of the pristine polymer and nanocomposite films were determined by differential scanning calorimetry (DSC, TA instruments, 2910, USA) at a heating rate of $10^{\circ} \mathrm{C} /$ min from $40^{\circ} \mathrm{C}$ to $240^{\circ} \mathrm{C}$ in $\mathrm{N}_{2}$ atmosphere. Tensile tests were performed on a universal testing machine (Instron 5567, NY, USA) to determine the tensile modulus, elongation at break and yield strength of the neat nylon 6 and nylon 6/clay nanocomposite films according to ASTM D 882. Oxygen permeability measurements of nylon 6/clay nanocomposite films and neat nylon 6 films were carried out at $23{ }^{\circ} \mathrm{C}$, $0 \% \mathrm{RH}$, atmospheric pressure using an oxygen permeation analyzer (Illinois 8000 Illinois instrument, USA). According to ASTM D 3985, the amounts of oxygen that permeated through the films were detected in units of $\mathrm{cc}^{-} \mathrm{m}^{-2} \cdot \mathrm{day}^{-1} \cdot \mathrm{atm}^{-1}$.

\section{Results and discussion}

\subsection{Degree of clay dispersion in nylon 6/clay nanocomposite films}

The degree of clay dispersion in a polymer matrix is known to affect its degree of crystallinity, which in turn affects the mechanical and barrier properties of the resulting polymer/clay nanocomposites. In particular, a nanocomposite with exfoliated clay platelets throughout the polymer matrix is expected to exhibit superior properties due to the high aspect ratio of clay and large interfacial area between the polymer matrix and layered silicates of the clay. The XRD patterns of the pristine clay, and the unmixed $\mathrm{M}_{3} \mathrm{~T}$ and $\mathrm{M}_{2}(\mathrm{HT})_{2}$ organoclays are illustrated in Fig. 2. In addition, the calculated interlayer spacing of clay is shown in Table 1. Obviously the peak of the pristine clay was found at $2 \theta=7.15^{\circ}$, corresponding to an interlayer spacing of $1.23 \mathrm{~nm}$. The $\mathrm{M}_{3} \mathrm{~T}$ organoclay exhibited broad low peaks at $2 \theta=1.67^{\circ}, 3.31^{\circ}$ and $4.65^{\circ}$, corresponding to interlayer spacing of $5.27,2.67$ and $1.90 \mathrm{~nm}$, respectively, due to the different orientation of the surfactant molecules between the layered silicates. On the other hand, the $\mathrm{M}_{2}(\mathrm{HT})_{2}$ organoclay exhibited a tall peak at $2 \theta=2.45^{\circ}$ and a small peak at $2 \theta=4.88^{\circ}$, corresponding to interlayer spacing of 3.59 and $1.81 \mathrm{~nm}$, respectively, of the $\{001\}$ and $\{002\}$ planes of the clay.

The XRD patterns of the $\mathrm{M}_{3} \mathrm{~T}$ nanocomposite films with different organoclay loadings are shown in Fig. 3a. The XRD pattern of $1 \mathrm{wt} \% \mathrm{M}_{3} \mathrm{~T}$ nanocomposite film was essentially flat and only a small shoulder was barely visible at $2 \theta=1.96^{\circ}$ because of the almost completely exfoliated state of the clay platelets in the nylon 6 matrix. On the other hand, the increasingly broad and tall XRD peaks of the $\mathrm{M}_{3} \mathrm{~T}$ nanocomposite films with 3,5 and $7 \mathrm{wt} \%$ of organoclay loading, respectively, were observed at $2 \theta=2.02^{\circ}, 2.46^{\circ}$ and $2.60^{\circ}$, which corresponded to interlayer spacing of $4.38,3.58$ and $3.40 \mathrm{~nm}$, respectively. In other words, the interlayer spacing between the layered silicates of the organoclay decreased as the organoclay loading increased. The broad tall XRD peaks indicate the disordered state of clay platelets in the nylon 6 matrix. The observation might be attributed to the degradation of the ammonium ions within the layered silicates $[8,10]$, the shifting from a dilute to a concentrated solution system of the clay in polymer matrix, the rearrangement of the surfactant between the layered silicates $[26,27]$ while melt mixing nylon 6 with the $\mathrm{M}_{3} \mathrm{~T}$ organoclay, or a combination of these three. In any case, the clay platelets tended to be packed closely to reduce the system's free energy and make the system thermodynamically favorable. The XRD interpretation results were confirmed by the TEM image in Fig. 4. Both individual clay platelets and stacks of clay platelets were observed in $\mathrm{M}_{3} \mathrm{~T}$ nanocomposite films with $3 \mathrm{wt} \%$ of organoclay loading. As we will see, both the state of clay dispersion and the amount of clay loading should affect the solid-state properties of $\mathrm{M}_{3} \mathrm{~T}$ nanocomposite films such as the mechanical and barrier properties. 
Table 1. Diffraction peak and interlayer spacing of pristine clay, organoclay and nylon $6 /$ clay nanocomposite films.

\begin{tabular}{|c|c|c|}
\hline Sample & $2 \theta\left({ }^{\circ}\right)$ & $\begin{array}{r}\text { Interlayer } \\
\text { spacing (nm) }\end{array}$ \\
\hline Pristine clay & $7.15(001)$ & $1.23(001)$ \\
\hline $\mathrm{M}_{3} \mathrm{~T}$ organoclay & $\begin{array}{l}1.67(001) \\
3.31(001) \\
4.65(001)\end{array}$ & $\begin{array}{l}5.27(001) \\
2.67(001) \\
1.90(001)\end{array}$ \\
\hline $1 \mathrm{wt} \% \mathrm{M}_{3} \mathrm{~T}$ film & $1.96(001)$ & $4.51(001)$ \\
\hline $3 \mathrm{wt} \% \mathrm{M}_{3} \mathrm{~T}$ film & $2.02(001)$ & $4.38(001)$ \\
\hline $5 \mathrm{wt}^{0} \% \mathrm{M}_{3} \mathrm{~T}$ film & $2.46(001)$ & $3.58(001)$ \\
\hline $7 \mathrm{wt} \% \mathrm{M}_{3} \mathrm{~T}$ film & $2.60(001)$ & $3.40(001)$ \\
\hline $\begin{array}{l}\mathrm{M}_{2}(\mathrm{HT})_{2} \\
\text { organoclay }\end{array}$ & $\begin{array}{l}2.45(001) \\
4.88(002) \\
7.36(003)\end{array}$ & $\begin{array}{l}3.59(001) \\
1.81(002) \\
1.20(003)\end{array}$ \\
\hline $\begin{array}{l}1 \mathrm{wt}^{\circ} \% \mathrm{M}_{2}(\mathrm{HT})_{2} \\
\text { film }\end{array}$ & $\begin{array}{l}2.00(001) \\
4.59(002)\end{array}$ & $\begin{array}{l}4.40(001) \\
1.92(002)\end{array}$ \\
\hline $\begin{array}{l}3 \mathrm{wt}^{0} \% \mathrm{M}_{2}(\mathrm{HT})_{2} \\
\text { film }\end{array}$ & $\begin{array}{l}2.33(001) \\
4.57(002)\end{array}$ & $\begin{array}{l}3.79(001) \\
1.93(002)\end{array}$ \\
\hline $\begin{array}{l}5 \mathrm{wt}^{\circ} \% \mathrm{M}_{2}(\mathrm{HT})_{2} \\
\text { film }\end{array}$ & $\begin{array}{l}2.35(001) \\
4.63(002)\end{array}$ & $\begin{array}{l}3.75(001) \\
1.90(002)\end{array}$ \\
\hline $\begin{array}{l}7 \mathrm{wt} \% \mathrm{M}_{2}(\mathrm{HT})_{2} \\
\text { film }\end{array}$ & $\begin{array}{l}2.34(001) \\
4.62(002)\end{array}$ & $\begin{array}{r}3.77(001) \\
1.91(002)\end{array}$ \\
\hline
\end{tabular}




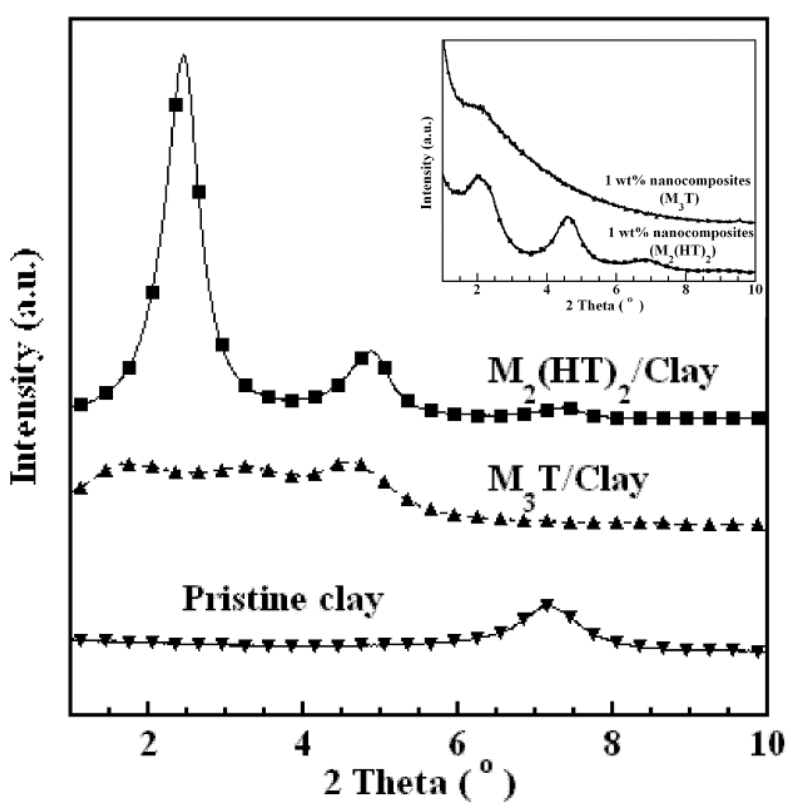

Fig. 2. XRD patterns of pristine clay, $\mathrm{M}_{3} \mathrm{~T}$ and $\mathrm{M}_{2}(\mathrm{HT})_{2}$ organoclays with insertion of XRD patterns of $\mathrm{M}_{3} \mathrm{~T}$ and $\mathrm{M}_{2}(\mathrm{HT})_{2}$ nylon 6/clay nanocomposite films at $1 \mathrm{wt} . \%$ organoclay loading.
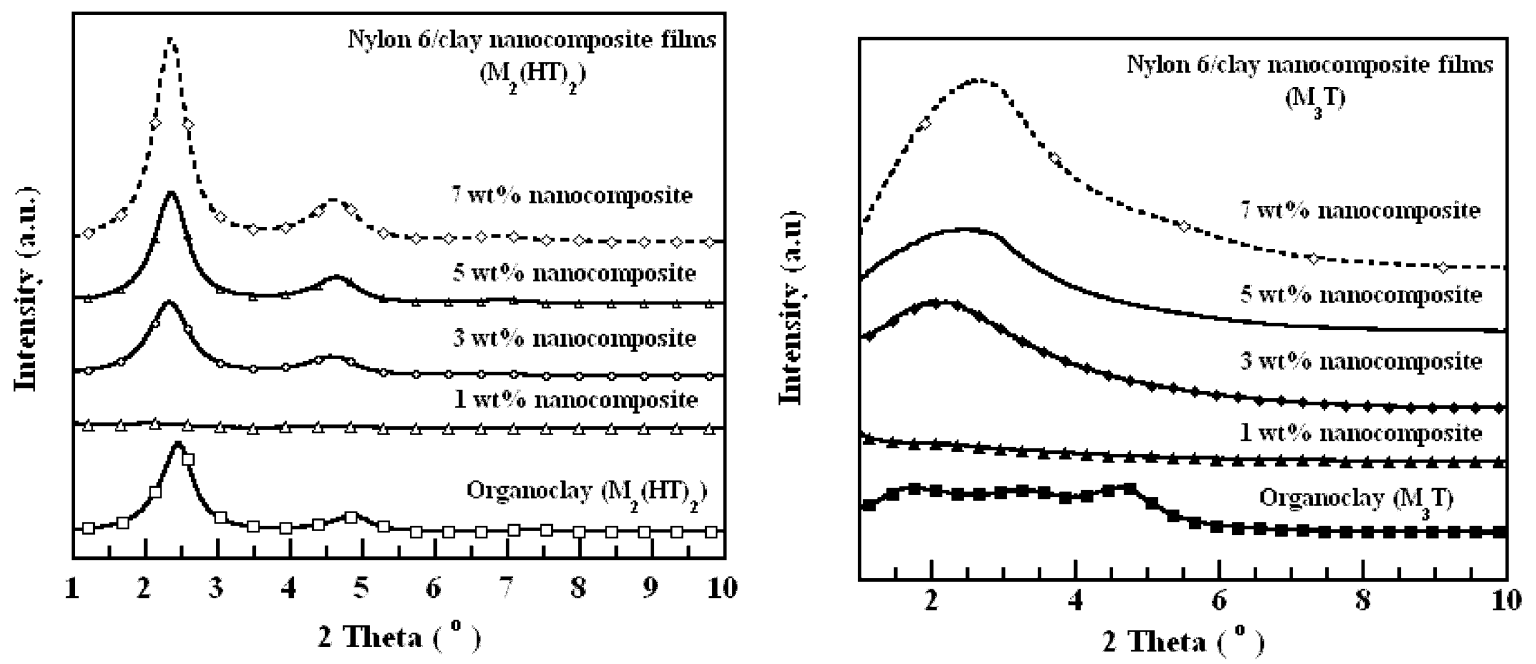

Fig. 3. XRD patterns of organoclay and nylon 6/clay nanocomposite films with different organoclay loadings (a) case of $\mathrm{M}_{3} \mathrm{~T}$ (b) case of $\mathrm{M}_{2}(\mathrm{HT})_{2}$. 


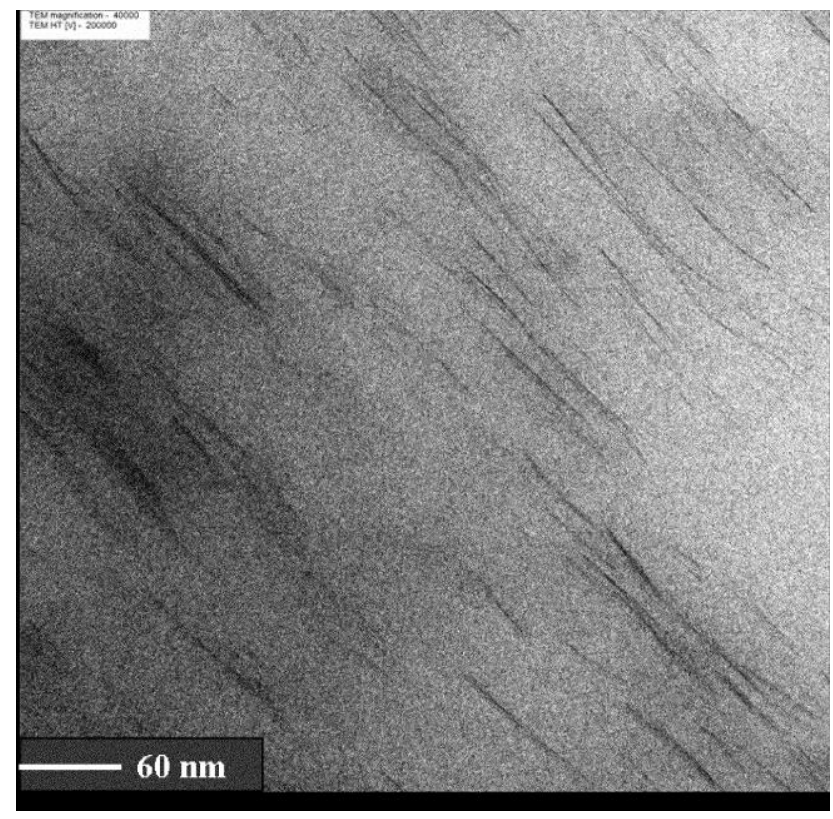

Fig. 4. TEM micrograph of $\mathrm{M}_{3}$ T nylon $6 /$ clay nanocomposite films with 3 wt. $\%$ organoclay loading.

Both the inserted figure in Fig. 2 and Fig. $3 \mathrm{~b}$ reveal that the XRD pattern of $1 \mathrm{wt} \% \mathrm{M}_{2}(\mathrm{HT})_{2}$ nanocomposite films exhibited two peaks at $2 \theta=2.00^{\circ}$ and $4.59^{\circ}$, corresponding to the interlayer spacing of 4.40 and $1.92 \mathrm{~nm}$, respectively. Note that the scale on the y-axis (intensity) of Fig. 3 is not the same as that of the inserted figure in Fig. 2. In other words, it's the authors' intention to show the small diffraction peaks of $1 \mathrm{wt} \% \mathrm{M}_{2}(\mathrm{TH})_{2}$ nanocomposite at $2 \theta=2.00^{\circ}$ and $4.59^{\circ}$, which we cannot see from Fig. 3b. The slightly wider spacing than that of the pure $\mathrm{M}_{2}(\mathrm{HT})_{2}$ organoclay indicated the partial insertion of polymer chains between the clay platelets. Interestingly, the diffraction peaks of all other $\mathrm{M}_{2}(\mathrm{HT})_{2}$ nanocomposite films were essentially shifted to two higher angle values of $2 \theta=2.33^{\circ}$ and $4.57^{\circ}$, respectively, which corresponded to the same interlayer spacing of 3.79 and $1.93 \mathrm{~nm}$, respectively. This indicates the same degree of clay dispersion for the 3,5 and $7 \mathrm{wt} \% \mathrm{M}_{2}(\mathrm{HT})_{2}$ nanocomposite films. Meanwhile, the diffraction intensity was found to increase as the organoclay loading increased due to the large amount of clay platelets that diffract X-ray.

The above XRD results reveal that the $\mathrm{M}_{3} \mathrm{~T}$ nanocomposite films showed a higher degree of clay dispersion than the corresponding $\mathrm{M}_{2}(\mathrm{HT})_{2}$ nanocomposite films for all organoclay loadings. More specifically, in the case of $1 \mathrm{wt} \%$ loading, the diffraction peak of the $\mathrm{M}_{3} \mathrm{~T}$ nanocomposite film was nearly flat while that of the $\mathrm{M}_{2}(\mathrm{HT})_{2}$ nanocomposite film exhibited two small peaks. Similarly, at 3, 5 and $7 \mathrm{wt} \%$ organoclay loadings, the XRD peaks of the $\mathrm{M}_{3} \mathrm{~T}$ nanocomposite films were much broader than those of the $\mathrm{M}_{2}(\mathrm{HT})_{2}$ films, thereby confirming the more disordered or random state of the clay platelets in the $\mathrm{M}_{3} \mathrm{~T}$ films.

\subsection{Crystalline structure of nylon 6 in the nylon 6/clay nanocomposite films}

After the interlayer spacing of the clay platelets was investigated, the crystalline structures of nylon 6 in the neat film and nanocomposite films could also be analyzed by means of the XRD technique in the range of $2 \theta=18-28^{\circ}$. Fig. 5a presents the XRD patterns of the crystalline structures of neat nylon 6 and the $\mathrm{M}_{3} \mathrm{~T}$ nanocomposite films with different organoclay loadings. The XRD peak at around $2 \theta=21.4^{\circ}$ which corresponded to the $\gamma$-crystalline phase of nylon 6 was observed for neat nylon 6 and all $\mathrm{M}_{3} \mathrm{~T}$ nanocomposite films. The peak area of the $\gamma$-crystalline phase of nylon 6 increased 11.3 times upon addition of $3 \mathrm{wt} \%$ of organoclay, thereby indicating a significant increase in the degree of crystallinity of the nylon 6 . This means that the layered silicates of the organoclay served as heterogeneous nucleating agent. However, the said peak area instead decreased when the organoclay loading was further increased to $5 \mathrm{wt} \%$. It may be considered that an excess of the clay platelets hindered the crystallization process. Note that all XRD patterns in Fig. 5a and 5b are plotted with the same intensity scales; however, the numeric and unit on y axis are not shown due to the cascade data. 


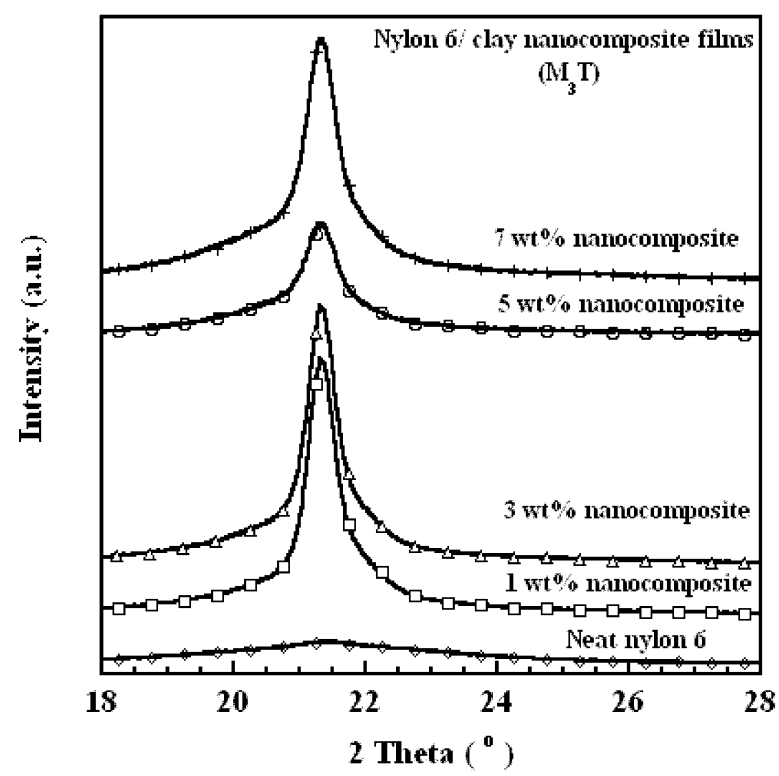

(a)

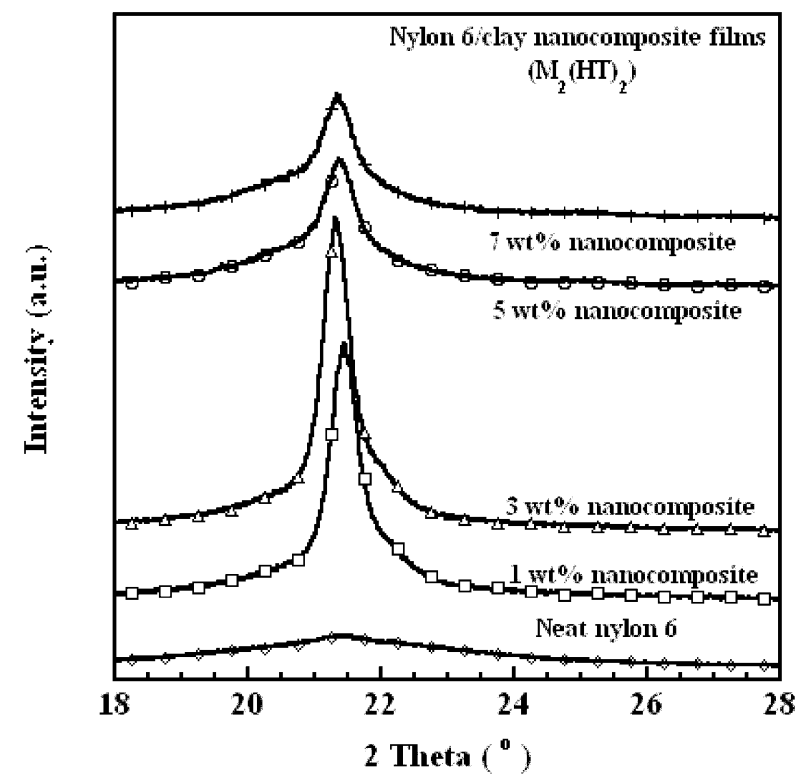

(b)

Fig. 5. XRD patterns associated with the crystalline phase of nylon 6 and its nanocomposite films with different organoclay loadings: (a) case of $\mathrm{M}_{3} \mathrm{~T}$; (b) case of $\mathrm{M}_{2}(\mathrm{HT})_{2}$.

Similarly, Fig. 5b shows that the diffraction peaks corresponding to the $\gamma$-crystalline phase of the nylon 6 in the $\mathrm{M}_{2}(\mathrm{HT})_{2}$ nanocomposite films appeared at the same $2 \theta$ value $\left(2 \theta=21.4^{\circ}\right)$ as that of the $\mathrm{M}_{3} \mathrm{~T}$ nanocomposite films. However, the peak areas of the $\mathrm{M}_{2}(\mathrm{HT})_{2}$ nanocomposite films was less than those of the corresponding $\mathrm{M}_{3} \mathrm{~T}$ nanocomposite films, thereby indicating a smaller degree of crystallinity for the $\mathrm{M}_{2}(\mathrm{HT})_{2}$ nanocomposite films. For instance, the peak areas corresponding to the degree of crystallinity of the $3 \mathrm{wt} \% \mathrm{M}_{2}(\mathrm{HT})_{2}$ and $\mathrm{M}_{3} \mathrm{~T}$ nanocomposite films increased by 9.6 and 11.3 times compared with that of neat nylon 6 films. When adding more than $5 \mathrm{wt} \%$ of the organoclay, the peak area corresponding to the $\gamma$ crystalline phase of nylon 6 began to decrease rapidly. It may be considered that, when organoclay was added over $3 \mathrm{wt} \%$, the excessive number of platelets tended to limit the growth of the nylon 6 crystallites between the layered silicates [18].

\subsection{Thermal behavior of nylon 6 and nylon $6 /$ clay nanocomposite films}

Figure 6a shows the DSC melting curves of neat nylon 6 and the $\mathrm{M}_{3} \mathrm{~T}$ nanocomposite films with different organoclay loadings. According to the DSC curve, the neat nylon 6 film showed a single crystalline-melting temperature $\left(\mathrm{T}_{\mathrm{m}}\right)$ at $221.2{ }^{\circ} \mathrm{C}$, which corresponded to the $\alpha$-crystalline phase of nylon 6 and was an obvious contradiction to the XRD result. This discrepancy might be ascribed to the rearrangement during heating of polymer chains in the $\gamma$ form to the more stable $\alpha$-crystalline phase. At all organoclay loadings, the $\mathrm{M}_{3} \mathrm{~T}$ nanocomposite films exhibited two melting peaks at 209.6 and $220.3{ }^{\circ} \mathrm{C}$ which corresponded to the $\gamma$ - and $\alpha$-crystalline phases, respectively, of nylon 6 . In fact the $\alpha$-crystalline phase of the nylon 6 matrix was dominant in all nanocomposites. Furthermore, the $\alpha$-crystalline peak area decreased as the organoclay loading increased but the $\gamma$-crystalline peak became sharper as the loading increased up to $5 \mathrm{wt} \%$, beyond which the area started to decrease. This indicated that the addition of the organoclay into the nylon 6 matrix enhanced the formation of the $\gamma$-crystalline phase of nylon 6 , which was consistent with Fornes $e t$ al. [18], Jiang et al. [11] and Liu et al. [7]. As shown in Fig. 6b, a similar trend of the DSC profiles was also observed for the $\mathrm{M}_{2}(\mathrm{HT})_{2}$ nanocomposite films. At all organoclay loadings, the $\mathrm{M}_{2}(\mathrm{HT})_{2}$ nanocomposite films exhibited two melting peaks at 210.0 and $220.0{ }^{\circ} \mathrm{C}$, respectively, which corresponded to the $\gamma$ - and $\alpha$ crystalline phases of nylon 6 . Upon the addition of only $1 \mathrm{wt} \%$ of $\mathrm{M}_{2}(\mathrm{HT})_{2}$ organoclay, the $\gamma$-crystalline phase of nylon 6 appeared sharply. The $\gamma$-phase decreased gradually as the organoclay loading further increased.

In short, it should be noted that the addition of organoclay into the nylon 6 matrix increased the $\gamma$ crystalline phase of nylon 6 because the added layered silicates into nylon 6 matrix enhanced the rate of crystallization, which was evident from the higher crystallization temperature upon the increasing organoclay loading as shown in Fig. 7. It may be considered that the layered silicates serve as heterogeneous 
nucleating agent.[28] However, the lower crystallization temperature could be observed at high organoclay loading because the diffusion of nylon 6 chains to be incorporated and formed as crystalline parts in the space between layered silicates was hindered at high organoclay loading. Although the degree of crystallinity of the nylon 6 matrix can be determined from both the DSC and XRD data, the DSC heating curve was less reliable than the XRD peak because the polymer chains could rearrange and form other stable crystalline part during heating.[22] Therefore, the degree of crystallinity obtained from the XRD peak will be used in all subsequent discussion.

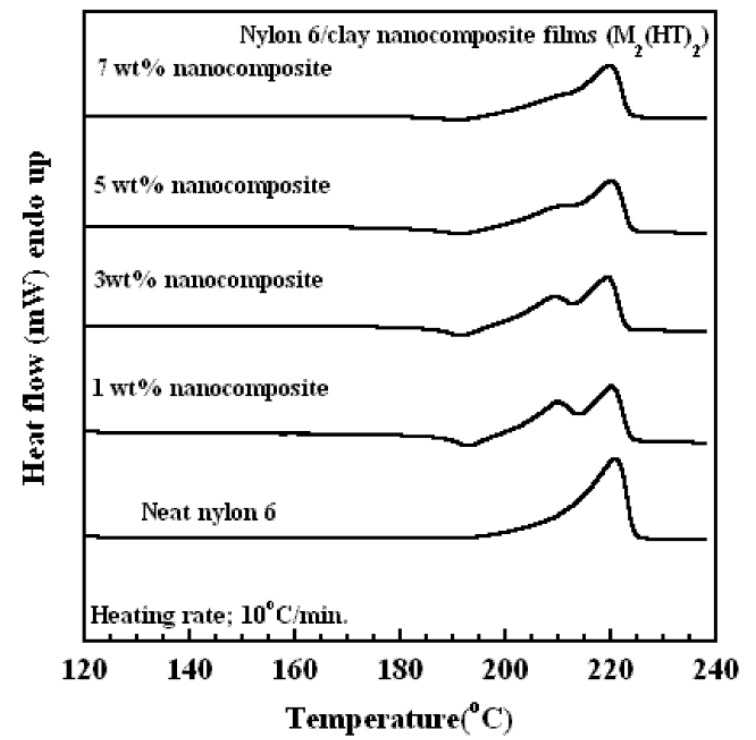

(a)

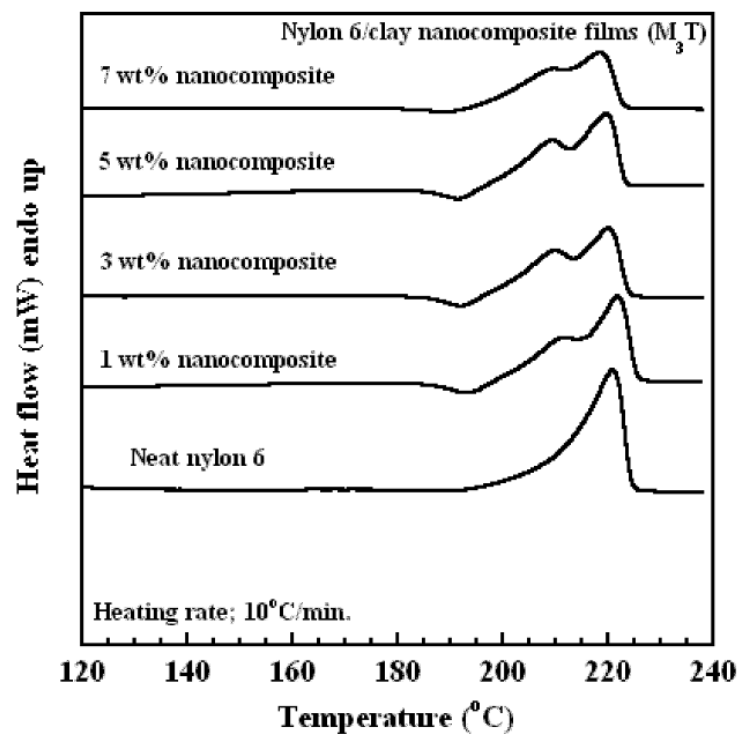

(b)

Fig. 6. DSC heating profiles of nylon 6 and nanocomposite films with different organoclay loading: (a) case of $\mathrm{M}_{3} \mathrm{~T}$; (b) case of $\mathrm{M}_{2}(\mathrm{HT})_{2}$.

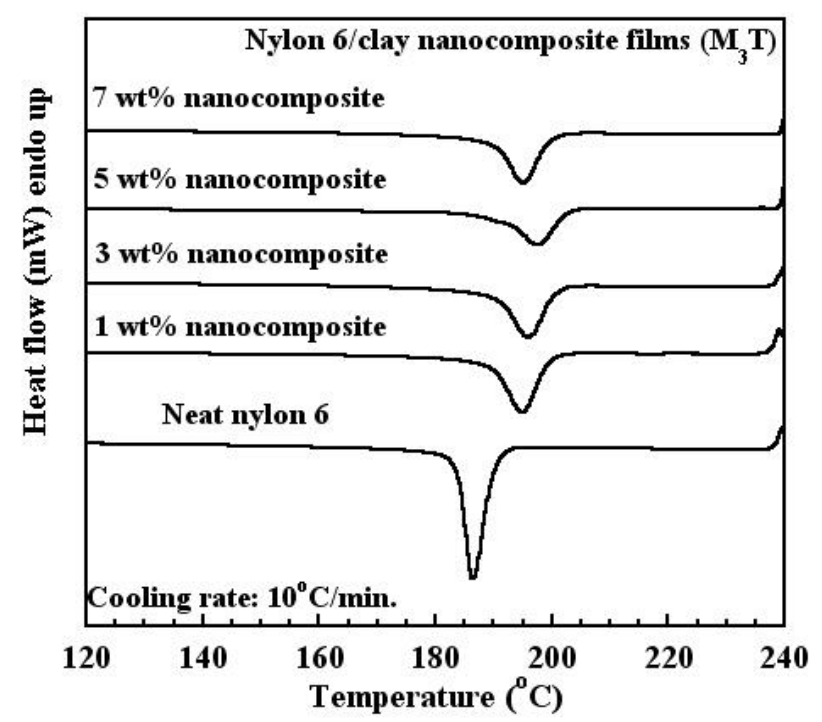

(a)

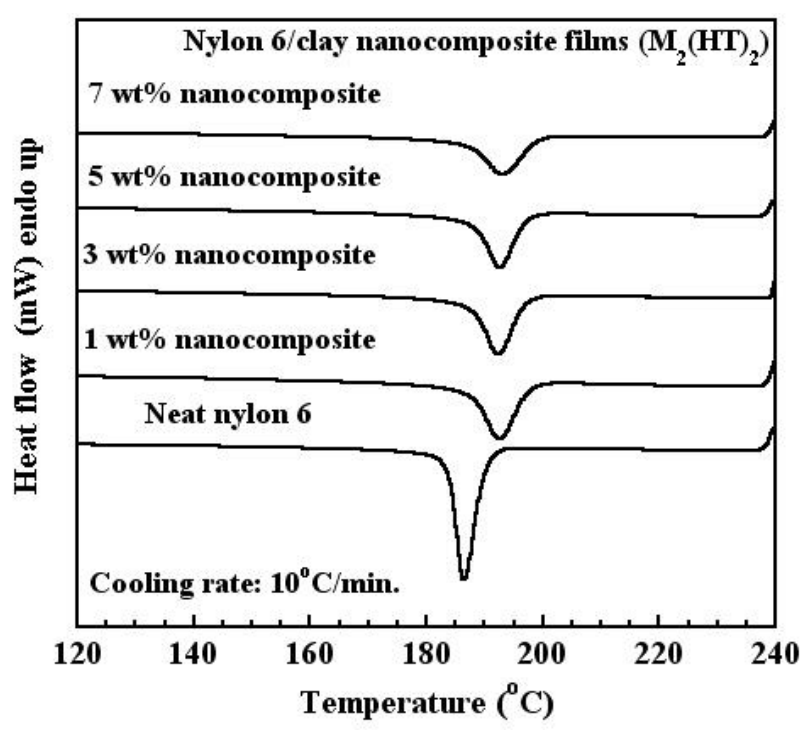

(b)

Fig. 7. DSC cooling profiles of nylon 6 and organoclay nanocomposite films at different organoclay loading: (a) case of $\mathrm{M}_{3} \mathrm{~T}$; (b) case of $\mathrm{M}_{2}(\mathrm{HT})_{2}$.

\subsection{Mechanical properties of nylon 6 and nylon $6 /$ clay nanocomposite films}

The tensile properties in both the machine direction (MD) and transverse direction (TD) of neat nylon 6 as well as the $\mathrm{M}_{3} \mathrm{~T}$ and $\mathrm{M}_{2}(\mathrm{HT})_{2}$ nanocomposite films with different organoclay loadings are summarized in 
Table 2. As expected, the tensile modulus and yield strength of all nanocomposite films increased in both the TD and MD as the organoclay content increased. In fact, the MD tensile modulus and yield strength of the $7 \mathrm{wt} \% \mathrm{M}_{3} \mathrm{~T}$ nanocomposite film were 2.7 and 1.6 times, respectively, of the neat nylon 6 film. Meanwhile, the corresponding TD values of the $5 \mathrm{wt} \% \mathrm{M}_{3} \mathrm{~T}$ nanocomposite film were 1.8 and 1.4 times, respectively, of the neat nylon 6 film. On the other hand, the corresponding MD values of the $3 \mathrm{wt} \%$ $\mathrm{M}_{2}(\mathrm{HT})_{2}$ nanocomposite film increased only 30 and $29 \%$, respectively, compared to the neat nylon 6 film. In addition, these values slightly decreased when the $\mathrm{M}_{2}(\mathrm{HT})_{2}$ organoclay exceeded $3 \mathrm{wt} \%$. The enhancement of the tensile modulus and yield strength for both the $\mathrm{M}_{3} \mathrm{~T}$ and $\mathrm{M}_{2}(\mathrm{HT})_{2}$ nanocomposite films could be attributed to the presence of the compatible organoclay filler that acts as reinforcing agent, the good dispersion of the organoclay in the polymer matrix and the increase in the degree of crystallinity of the nylon 6 matrix. Nevertheless, as discussed earlier, the tensile modulus and yield strength of the $\mathrm{M}_{2}(\mathrm{HT})_{2}$ nanocomposite films decreased after the organoclay content exceeded $3 \mathrm{wt} \%$ primarily because of the reduction in the degree of crystallinity.

The elongation at break of all nanocomposite films decreased with the presence of organoclay in the nylon 6 matrix because the dispersed clay platelets increased the film stiffness. For example, the elongation at break of the $7 \mathrm{wt} \% \mathrm{M}_{3} \mathrm{~T}$ nanocomposite films decreased by $51 \%$ compared to that of the neat nylon 6 film. The $\mathrm{M}_{3} \mathrm{~T}$ nanocomposite films exhibited higher stiffness than the corresponding $\mathrm{M}_{2}(\mathrm{HT})_{2}$ nanocomposite films at the same clay loading because of the significant difference in the degree of clay dispersion in the nylon 6 matrix. Nylon 6 is polar in nature and it can easily form hydrogen bonding within and between polymer chains. Therefore, the nylon 6 chains are capable of accessing the surfaces of the clay platelets. Since the size of the $\mathrm{M}_{3} \mathrm{~T}$ surfactant was significantly smaller than $\mathrm{M}_{2}(\mathrm{HT})_{2}$ surfactant, the nylon 6 chains could more intimately interact with the $\mathrm{M}_{3}$ T organoclay platelets than the $\mathrm{M}_{2}(\mathrm{HT})_{2}$ ones. As a result, the $\mathrm{M}_{3} \mathrm{~T}$ nanocomposite films exhibited a higher degree of clay dispersion than the $\mathrm{M}_{2}(\mathrm{HT})_{2}$ ones, which was confirmed by XRD analysis. The better dispersion contributed to higher enhancements of the solidstate mechanical properties. In either case, the presence of the layered silicate of the clay and the degree of crystallinity of the polymer also enhanced the stiffness of the composite materials.

As expected, the orientation of the clay platelets also affected the solid-state mechanical properties of the nanocomposite films. In the present study, the nanocomposite films were formed with the use of a twin screw extruder attached to a blown film die while the polymer chains were drawn in the machine direction. In Table 2, the values of the tensile modulus of the neat nylon 6 film were only slightly different in the MD and TD directions. However, the MD tensile modulus of the $7 \mathrm{wt} \% \mathrm{M}_{3} \mathrm{~T}$ nanocomposite films turned out to be 1.6 times higher than the TD one. Logically, because of the shear forces, the clay platelets would be forced to align themselves in the direction of the flow or machine direction but not in the transverse direction of the film. As a result, the aligned layered silicates would reinforce the polymer film more in the machine direction than the transverse direction.

\subsection{Gas barrier performance of nylon $6 /$ clay nanocomposite films}

The oxygen permeability of the neat nylon 6 film as well as the $\mathrm{M}_{3} \mathrm{~T}$ and $\mathrm{M}_{2}(\mathrm{HT})_{2}$ nanocomposite films with different organoclay contents are also listed in Table 2. Originally the oxygen permeability of the $\mathrm{M}_{3} \mathrm{~T}$ nanocomposite films was expected to decrease compared with that of the neat nylon 6 film because the added clay platelets would create tortuous pathways for the passage of oxygen. For example, the oxygen permeation rate of the $5 \mathrm{wt}^{\%} \mathrm{M}_{3} \mathrm{~T}$ nanocomposite films decreased by $27 \%$ compared to that of the neat nylon 6 film. Unexpectedly, the oxygen permeability of $\mathrm{M}_{2}(\mathrm{HT})_{2}$ nanocomposite films gradually increased as the organoclay loading increased. From the XRD results, the $\mathrm{M}_{3} \mathrm{~T}$ nanocomposite films showed significantly broader peaks compared those of the corresponding $\mathrm{M}_{2}(\mathrm{HT})_{2}$ films. This means that the melt mixing process created disordered structure of $\mathrm{M}_{3} \mathrm{~T}$ organoclay randomly dispersed throughout nylon 6 matrix. However, the narrower XRD peaks of the $\mathrm{M}_{2}(\mathrm{HT})_{2}$ nanocomposite films were located at essentially the same positions as that of the $\mathrm{M}_{2}(\mathrm{HT})_{2}$ organoclay, thereby indicating that the clay platelets were in ordered state and did not randomly disperse throughout the polymer matrix. Consequently, the oxygen permeation rate of the $\mathrm{M}_{3} \mathrm{~T}$ nanocomposite films was generally significantly lower than that of the corresponding $\mathrm{M}_{2}(\mathrm{HT})_{2}$ nanocomposite films. Not only the presence of the clay platelets but a change in the crystalline phase of nylon 6 also improved oxygen barrier properties. The interplanar spacing of the $\gamma$ crystalline phase of nylon 6 was narrower than that of the $\alpha$-crystalline phase, thereby resulting in a reduction of the free volume of nylon 6. 
Table 2. Tensile properties in both machine and transverse directions, and oxygen transmission rate of nylon 6/clay nanocomposite films.

\begin{tabular}{|c|c|c|c|c|c|c|c|}
\hline \multirow{2}{*}{$\begin{array}{l}\text { PA6/clay } \\
\text { nanocomposite } \\
\text { film }\end{array}$} & \multicolumn{2}{|c|}{$\begin{array}{l}\text { Tensile modulus } \\
\text { (MPa) }\end{array}$} & \multicolumn{2}{|c|}{$\begin{array}{c}\text { Tensile } \\
\text { strength at } \\
\text { yield (MPa) }\end{array}$} & \multicolumn{2}{|c|}{$\begin{array}{c}\text { Elongation at } \\
\text { break (\%) }\end{array}$} & \multirow{2}{*}{$\begin{array}{c}\mathrm{O}_{2} \mathrm{TR} \\
\text { (cc.mil/m } \mathrm{m}^{2} . \mathrm{day} \\
\mathrm{atm})\end{array}$} \\
\hline & MD & TD & MD & TD & MD & TD & \\
\hline Neat PA6 & $\begin{array}{l}351.26 \pm \\
35.02\end{array}$ & $\begin{array}{l}334.97 \pm \\
21.46\end{array}$ & $\begin{array}{r}21.03 \\
\pm 0.88\end{array}$ & $\begin{array}{r}20.05 \\
\pm 0.91\end{array}$ & $\begin{array}{c}163.78 \pm \\
16.38\end{array}$ & $\begin{array}{l}248.99 \\
\pm 24.43\end{array}$ & $72.07 \pm 7.00$ \\
\hline $1 \mathrm{wt}^{0} \% \mathrm{M}_{3} \mathrm{~T}$ & $\begin{array}{c}543.75 \pm \\
29.71\end{array}$ & $\begin{array}{c}344.43 \pm \\
28.17\end{array}$ & $\begin{array}{r}29.65 \\
\pm 1.88\end{array}$ & $\begin{array}{l}24.97 \\
\pm 1.85\end{array}$ & $\begin{array}{c}112.89 \pm \\
12.81\end{array}$ & $\begin{array}{r}238.55 \\
\pm 33.03\end{array}$ & $69.41 \pm 0.47$ \\
\hline $3 \mathrm{wt}^{0} \% \mathrm{M}_{3} \mathrm{~T}$ & $\begin{array}{l}712.82 \pm \\
38.42\end{array}$ & $\begin{array}{c}570.97 \pm \\
46.71\end{array}$ & $\begin{array}{r}31.54 \\
\pm 1.47\end{array}$ & $\begin{array}{r}25.83 \\
\pm 2.11\end{array}$ & $\begin{array}{c}89.67 \pm \\
12.46\end{array}$ & $\begin{array}{r}192.38 \\
\pm 30.98\end{array}$ & $80.09 \pm 0.58$ \\
\hline $5 \mathrm{wt} \% \mathrm{M}_{3} \mathrm{~T}$ & $\begin{array}{l}868.51 \pm \\
41.71\end{array}$ & $\begin{array}{c}601.62 \pm \\
42.88\end{array}$ & $\begin{array}{r}32.54 \\
\pm 1.78\end{array}$ & $\begin{array}{l}28.37 \\
\pm 3.74\end{array}$ & $\begin{array}{c}86.24 \pm \\
13.17\end{array}$ & $\begin{array}{l}180.71 \\
\pm 25.01\end{array}$ & $52.84 \pm 4.93$ \\
\hline $7 \mathrm{wt}^{\circ} \% \mathrm{M}_{3} \mathrm{~T}$ & $\begin{array}{c}939.12 \pm \\
43.80\end{array}$ & $\begin{array}{l}594.95 \pm \\
48.10\end{array}$ & $\begin{array}{r}32.85 \\
\pm 1.59\end{array}$ & $\begin{array}{l}27.26 \\
\pm 2.61\end{array}$ & $\begin{array}{l}79.43 \pm \\
13.12\end{array}$ & $\begin{array}{l}178.29 \\
\pm 36.36\end{array}$ & $56.50 \pm 0.77$ \\
\hline $1 \mathrm{wt} \% \mathrm{M}_{2}(\mathrm{HT})_{2}$ & $\begin{array}{l}447.06 \pm \\
37.55\end{array}$ & $\begin{array}{l}340.01 \pm \\
35.05\end{array}$ & $\begin{array}{r}26.40 \\
\pm 1.40\end{array}$ & $\begin{array}{l}23.87 \\
\pm 1.56\end{array}$ & $\begin{array}{c}117.12 \pm \\
11.94\end{array}$ & $\begin{array}{l}241.31 \\
\pm 19.60\end{array}$ & $71.31 \pm 5.17$ \\
\hline $3 \mathrm{wt} \% \mathrm{M}_{2}(\mathrm{HT})_{2}$ & $\begin{array}{l}457.99 \pm \\
58.33\end{array}$ & $\begin{array}{c}366.33 \pm \\
32.41\end{array}$ & $\begin{array}{r}27.15 \\
\pm 1.86\end{array}$ & $\begin{array}{l}24.84 \\
\pm 1.60\end{array}$ & $\begin{array}{c}102.40 \pm \\
16.69\end{array}$ & $\begin{array}{l}199.11 \\
\pm 23.74\end{array}$ & $77.02 \pm 0.90$ \\
\hline $5 \mathrm{wt}^{0} \% \mathrm{M}_{2}(\mathrm{HT})_{2}$ & $\begin{array}{l}430.70 \pm \\
44.78\end{array}$ & $\begin{array}{l}337.32 \pm \\
33.70\end{array}$ & $\begin{array}{r}23.18 \\
\pm 2.19\end{array}$ & $\begin{array}{r}22.08 \\
\pm 1.11\end{array}$ & $\begin{array}{c}101.62 \pm \\
9.77\end{array}$ & $\begin{array}{l}236.83 \\
\pm 16.03\end{array}$ & $90.60 \pm 3.80$ \\
\hline $7 \mathrm{wt}^{2} \% \mathrm{M}_{2}(\mathrm{HT})_{2}$ & $\begin{array}{l}378.91 \pm \\
54.29\end{array}$ & $\begin{array}{c}342.22 \pm \\
30.68\end{array}$ & $\begin{array}{r}21.12 \\
\pm 1.19\end{array}$ & $\begin{array}{l}22.08 \\
\pm 2.22\end{array}$ & $\begin{array}{c}128.16 \pm \\
15.38\end{array}$ & $\begin{array}{l}230.86 \\
\pm 24.73\end{array}$ & $113.24 \pm 7.15$ \\
\hline
\end{tabular}

\section{Conclusion}

The effects of the surfactant type and organoclay loading on the crystallinity, degree of clay dispersion and the resulting solid-state properties of nylon 6/clay nanocomposites were extensively investigated. The $\mathrm{M}_{3} \mathrm{~T}$ organoclay modified with the single-chain surfactant shows a more disordered structure than the $\mathrm{M}_{2}(\mathrm{HT})_{2}$ organoclay modified with the double-chain surfactant. The XRD analysis confirmed that the $\mathrm{M}_{3} \mathrm{~T}$ nanocomposite films exhibited a higher degree of clay dispersion than the corresponding $\mathrm{M}_{2}(\mathrm{HT})_{2}$ nanocomposite films. In addition, both DSC and XRD results revealed that the addition of layered silicates induced $\gamma$-crystalline form of nylon 6 . The degree of crystallinity of the $\mathrm{M}_{3}$ T nanocomposite films was shown to be higher than that of the corresponding $\mathrm{M}_{2}(\mathrm{HT})_{2}$ nanocomposite films at the same organoclay loading. Since good dispersion of the clay platelets and a high degree of crystallinity of the nylon 6 matrix led to the enhancement of the mechanical and barrier properties of the nanocomposite films, the tensile modulus, yield strength and gas barrier properties of the $\mathrm{M}_{3} \mathrm{~T}$ films were much higher than those of the corresponding $\mathrm{M}_{2}(\mathrm{HT})_{2}$ films. Furthermore, all nylon 6/clay nanocomposite films exhibited higher mechanical properties in the machine direction than the transverse direction. 


\section{Acknowledgement}

The authors acknowledge financial support from Thailand Research Fund (TRF) and the Commission on Higher Education (CHE), Ministry of Education with the contract number MRG5180314.

\section{References}

[1] T. D. Fornes, P. J. Yoon, D. L. Hunter, H. Keskkula, and D. R. Paul, "Effect of organoclay structure on nylon 6 nanocomposite morphology and properties," Polymer, vol. 43, no. 22, pp. 5915-5933, 2002.

[2] T. D. Fornes, P. J. Yoon, H. Keskkula, and D. R. Paul, "Nylon 6 nanocomposites: the effect of matrix molecular weight," Polymer, vol. 42, no. 25, pp. 9929-9940, 2001.

[3] E. P. Giannelis, "Polymer Layered Silicate Nanocomposites," Advanced Materials, vol. 8, no. 1, pp. 2935, 1996.

[4] N. Hasegawa, H. Okamoto, M. Kato, A. Usuki, and N. Sato, "Nylon 6/Na-montmorillonite nanocomposites prepared by compounding Nylon 6 with Na-montmorillonite slurry," Polymer. vol. 44, no. 10, pp. 2933-2937, 2003.

[5] S. Hotta and D. R. Paul, "Nanocomposites formed from linear low density polyethylene and organoclays," Polymer, vol. 45, no. 22, pp. 7639-7654, 2004.

[6] L. Incarnato, P. Scarfato, G. M. Russo, L. D. Maio, P. Iannelli, and D. Acierno, "Preparation and characterization of new melt compounded copolyamide nanocomposites," Polymer, vol. 44, no. 16, pp. 4625-4634, 2003.

[7] T. X. Liu, Z. H. Liu, K. X. Ma, L. Shen, K. Y. Zeng, and C. B. He, "Morphology, thermal and mechanical behavior of polyamide 6/layered-silicate nanocomposites," Composites Science and Technology, vol. 63, no. 3-4, pp. 331-337, 2003.

[8] R. K. Shah and D. R. Paul, "Nylon 6 nanocomposites prepared by a melt mixing masterbatch process," Polymer, vol. 45, no. 9, pp. 2991-3000, 2004.

[9] D. P. N. Vlas veld, J. Groenewold, H. E. N. Bersee, and S. J. Picken, "Moisture absorption in polyamide- 6 silicate nanocomposites and its influence on the mechanical properties," Polymer, vol. 46, no. 26, pp. 12567-12576, 2005.

[10] S. Arunvisut, S. Phummanee, and A. Somwangthanaroj, "Effect of clay on mechanical and gas barrier properties of blown film LDPE/clay nanocomposites," Journal of Applied Polymer Science, vol. 106, no. 4, pp. 2210-2217, 2007.

[11] T. Jiang, Y. Wang, J. Yeh, and Z. Fan, "Study on solvent permeation resistance properties of nylon6/clay nanocomposite," European Polymer Journal, vol. 41, no. 3, pp. 459- 466, 2005.

[12] Z. Ke and B. Yongping, "Improve the gas barrier property of PET film with montmorillonite by in situ interlayer polymerization," Materials Letters, vol. 59, no. 27, pp. 3348-3351, 2005.

[13] M. A. Osman, J. E. P. Rupp, and U. W. Suter, "Gas permeation properties of polyethylene-layered silicate nanocomposites," Journal of Materials Chemistry, vol. 15, no. 12, pp. 1298-1304, 2005.

[14] X. Y. Meng, Z. Wang, Z. F. Zhao, X. H. Du, W. G. Bi, and T. Tang, "Morphology evolutions of organically modified montmorillonite/polyamide 12 nanocomposites," Polymer, vol. 48, no. 9, pp. 2508-2519, 2007.

[15] E. Picard, A. Vermogen, J. F. Gerard, and E. Espuche, "Barrier properties of nylon 6-montmorillonite nanocomposite membranes prepared by melt blending: Influence of the clay content and dispersion state - Consequences on modelling," Journal of Membrane Science, vol. 292, no. 1-2, pp. 133-144, 2007.

[16] G. M. Russo, G. P. Simon, and L. Incarnato, "Correlation between rheological, mechanical, and barrier properties in new copolyamide-based nanocomposite films," Macromolecules, vol. 39, no. 11, pp. 3855-3864, 2006.

[17] T. Y. Tsai, W. H. Lin, Y. Y. Lin, Y. C. Hsu, U. Ray, Y. T. Lin, and M. J. Ou, "Permeability property of Nylon 6 nanocomposite membranes with various clay minerals," Desalination, vol. 233, no. 1-3, pp. 183-190, 2008.

[18] T. D. Fornes and D. R. Paul, "Crystallization behavior of nylon 6 nanocomposites," Polymer, vol. 44, no. 14, pp. 3945-3961, 2003.

[19] Y. Kojima, A. Usuki, M. Kawasumi, A. Okada, Y. Fukushima, T. Kurauchi, and O. Kamigaito, "Mechanical properties of nylon 6-clay hybrid," Joumal of Materials Research, vol. 8, no. 5, pp. 1185-1189, 1993. 
[20] A. Usuki, Y. Kojima, M. Kawasumi, A. Okada, Y. Fukushima, T. Kurauchi, and O. Kamigaito, "Synthesis of nylon 6-clay hybrid," Journal of Materials Research, vol. 8, no. 5, pp. 1179-1184, 1993.

[21] A. Rehab and N. Salahuddin, "Nanocomposite materials based on polyurethane intercalated into montmorillonite clay," Materials Science and Engineering a-Structural Materials Properties Microstructure and Processing, vol. 399, no. 1-2, pp. 368-376, 2005.

[22] L. Penel-Pierron, R. Seguela, J. M. Lefebvre, V. Miri, C. Depecker, M. Jutigny, and J. Pabiot, "Structural and mechanical behavior of nylon-6 films. II. Uniaxial and biaxial drawing," Journal of Polymer Science Part B-Polymer Physics, vol. 39, no. 11, pp. 1224-1236, 2001.

[23] M. Ito, K. Mizuochi, and T. Kanamoto, "Effects of crystalline forms on the deformation behaviour of nylon-6," Polymer, vol. 39, no. 19, pp. 4593-4598, 1998.

[24] X. Liu and Q. Wu, "Phase transition in nylon 6/clay nanocomposites on annealing," Polymer, vol. 43, no. 6, pp. 1933-1936, 2002.

[25] Y. Kojima, A. Usuki, M. Kawasumi, A. Okada, T. Kurauchi, O. Kamigaito, and K. Kaji, "Fine structure of nylon-6-clay hybrid "Journal of Polymer Science Part B, Polymer Physics, vol. 32, no. 4, pp. 625630, 1994.

[26] Y. F. Xi, Z. Ding, H. P. He, and R. L. Frost, "Structure of organoclays-an x-ray diffraction and thermogravimetric analysis study," Journal of Colloid and Interface Science, vol. 277, no. 1, pp. 116-120, 2004.

[27] Q. H. Zeng, A. B. Yu, G. Q. Lu, and R. K. Standish, "Molecular dynamics simulation of the structural and dynamic properties of dioctadecyldimethyl ammoniums in organoclays," Journal of Physical Chemistry B, vol. 108, no. 28, pp. 10025-10033, 2004.

[28] A. Somwangthanaroj, E. C. Lee, and M. J. Solomon, "Early stage quiescent and flow-induced crystallization of intercalated polypropylene nanocomposites by time-resolved light scattering," Macromolecules, vol. 36, no. 7, pp. 2333-2342, 2003. 
